\title{
Nauczanie języków obcych w kontekście pracy indywidualnej ze studentem z niepełnosprawnością (np. deficytami ruchowymi, psychicznymi) - dydaktyka nauczania oraz logistyka współpracy z Biurem ds. Osób Niepełnosprawnych
}

\section{Zagadnienia administracyjno-prawne}

\subsection{Akty ogólne}

Prawo wszystkich obywateli do nauki, w tym do edukacji osób z niepełnosprawnościami - biorąc pod uwagę akty międzynarodowe - gwarantowane jest w pierwszej kolejności przez Konwencję ONZ o prawach osób niepełnosprawnych, ratyfikowaną przez Polskę 6 września 2012 $\mathrm{roku}^{1}$. Niezaprzeczalne prawo to ma również umocowanie $\mathrm{w}$ aktach

${ }^{1}$ Konwencja ONZ o prawach osób niepełnosprawnych (z 13 grudnia 2006):

„Art. 24 pkt. 5. Państwa Strony zapewnią, że osoby niepełnosprawne będą miały dostęp do powszechnego szkolnictwa wyższego, szkolenia zawodowego, kształcenia 
prawodawstwa polskiego, $\mathrm{w}$ tym przede wszystkim $\mathrm{w}$ Ustawie $\mathrm{z}$ dnia 27 lipca 2005 r. Prawo o szkolnictwie wyższym ${ }^{2}$ oraz w Rozporządzeniu Ministra Nauki i Szkolnictwa Wyższego z dnia 25 września 2014 r. w sprawie warunków, jakim muszą odpowiadać postanowienia regulaminu studiów na uczelniach wyższych ${ }^{3}$.

\subsection{Akt wewnątrzuczelniany - Regulamin Uniwersytetu Papieskiego Jana Pawła II w Krakowie}

Na podstawie wyżej wzmiankowanych aktów prawnych, zwłaszcza zaś w myśl wymienionego na ostatnim miejscu rozporządzenia, Uniwersytet Papieski Jana Pawła II w Krakowie wprowadził do obowiązującego od 1 października 2016 roku znowelizowanego Regulaminu studiów pierwszego stopnia, drugiego stopnia oraz jednolitych studiów magisterskich uszczegółowione zapisy dotyczące funkcjonowania pod kątem praw i obowiązków na uczelni studentów z niepełnosprawnością ${ }^{4}$ Adnotacja ta pojawiła się po raz pierwszy w tego typu aktach normatywnych UPJPII i jej obecność należy podkreślić.

Poniżej przytoczono te fragmenty regulaminu, które związane są z procesem kształcenia językowego omawianej grupy słuchaczy, a które

dorosłych i możliwości uczenia się przez całe życie, bez dyskryminacji i na zasadzie równości z innymi osobami. W tym celu Państwa Strony zagwarantują, że zapewnione będą racjonalne usprawnienia dla osób niepełnosprawnych.” Zob. https://www.rpo.gov.pl/pl/ konwencja-o-prawach-osob-niepelnosprawnych (13.11.2016).

${ }^{2}$ Ustawa z dnia 27 lipca 2005 r. Prawo o szkolnictwie wyższym (Dz.U. z 2012, poz. 572): „Art. 13 ust. 1 pkt. 9. Podstawowymi zadaniami uczelni, z zastrzeżeniem ust. 2 i 3 , są: stwarzanie osobom niepełnosprawnym warunków do pełnego udziału w:

a) procesie kształcenia,

b) badaniach naukowych."

${ }^{3}$ Rozporządzenie Ministra Nauki i Szkolnictwa Wyższego z dnia 25 września 2014 r. w sprawie warunków, jakim muszą odpowiadać postanowienia regulaminu studiów w uczelniach (Dz.U. z 2014, poz. 1302):

„2. Regulamin studiów określa sposób dostosowania organizacji i właściwej realizacji procesu dydaktycznego do szczególnych potrzeb studentów będącymi osobami niepełnosprawnymi, w tym dostosowania warunków odbywania studiów do rodzaju niepełnosprawności".

${ }^{4}$ Zob. http://www.upjp2.edu.pl/sites/default/files/Regulamin (12.11.2016). 
będą również przywoływane w dalszej części artykułu, dotyczącej sensu stricto sfery dydaktycznej w pracy ze studentem $\mathrm{z}$ niepełnosprawnością. Świadczą one o daleko posuniętej indywidualizacji tego obszaru aktywności w środowisku uniwersyteckim już na etapie zapisów regulaminowych:

„\$36 pkt 1: Uniwersytet wspiera proces dydaktyczny osób niepełnosprawnych poprzez stałą poprawę warunków kształcenia i podnoszenie standardów nauczania wszystkich osób niepełnosprawnych.

$\$ 36$ pkt 4: W zależności od rodzaju i stopnia niepełnosprawności studenta można stosować w szczególności:

1) wydłużenie czasu pisania testu, kolokwium i egzaminu;

2) zamianę formy egzaminu;

3) używanie komputera na zajęciach;

4) otrzymywanie testów, materiałów w dogodnej dla studenta formie;

5) wykonywanie zdjęć, kopiowanie foliogramów, prezentacji z zajęć lub ich przesyłanie w formie elektronicznej;

6) nagrywanie wykładów na dyktafon;

7) możliwość zdawania materiału w mniejszych partiach;

8) korzystanie przez studenta ze sprzętu wspomagającego zdolność czytania lub słyszenia.

$\$ 36$ pkt 13: Studentowi niepełnosprawnemu przysługuje prawo do uczestnictwa w alternatywnych lektoratach z języków obcych. Organizacją tych lektoratów zajmuje się Biuro ds. Osób Niepełnosprawnych, przy współpracy z Międzywydziałowym Studium Języków Obcych.”

\subsection{Porozumienie uczelni wyższych w Krakowie.}

Należy zwrócić uwagę na fakt, że w Krakowie od 15 listopada 2007 roku istnieje unikatowa w skali kraju formuła funkcjonowania kilku uczelni wyższych, które zdecydowały się na zawarcie porozumienia, mającego na celu wymianę wzajemnych doświadczeń w zakresie wyrównywania szans studentów z niepełnosprawnością ${ }^{5}$. Porozumienie to, początkowo zawarte pomiędzy trzema uczelniami (Uniwersytetem Ekonomicznym,

${ }^{5}$ Zob. Jedyne w swoim rodzaju Porozumienie międzyuczelniane, http://www.up.krakow.pl/bon/wspolpraca.html (13.11.2016). 
Akademią Górniczo-Hutniczą i Politechniką Krakowską), z czasem rozrosło się do organizacji skupiającej siedem krakowskich wszechnic (jako ostatni w 2015 roku przystąpił do niego Uniwersytet Rolniczy). UPJPII stał się sygnatariuszem porozumienia 27 października 2010 roku. Wśród zapisów normujących pracę porozumienia jest również mowa o współpracy dotyczącej sfery zindywidualizowanego nauczania języków obcych. Stanowią one, co następuje:

„\$2 pkt 1: W ramach niniejszego Porozumienia Strony zobowiązują się do współpracy w zakresie:

$\$ 2$ pkt 1.9: organizowania lektoratów dostosowanych do potrzeb osób niepełnosprawnych.

$\$ 2$ pkt 1.11: udostępniania (w miarę możliwości) własnej bazy lokalowej lub wypożyczania i udostępniania własnego sprzętu oraz wykorzystywania kadry, po uzgodnieniu przez Strony warunków na piśmie".

W ramach tej współpracy, realizując cel zwiększenia wsparcia edukacyjnego i wychodząc naprzeciw potrzebom innych uczelni, z grona Międzywydziałowego Studium Języków Obcych UPJPII dwukrotnie do zajęć językowych była oddelegowywana lektorka - specjalista języka rosyjskiego - która pracowała ze studentem z niepełnosprawnością wzrokową na krakowskim Uniwersytecie Pedagogicznym ${ }^{6}$.

\subsection{Współpraca pomiędzy Międzywydziałowym Studium}

Języków Obcych a Biurem ds. Osób Niepełnosprawnych

Uniwersytetu Papieskiego Jana Pawła II w Krakowie

Niniejszy artykuł skupia się przede wszystkim na zajęciach prowadzonych przez pracowników MSJO indywidualnie dla studentów z niepełnoprawnościami, choć ogólna tendencja w omawianym temacie na poziomie szkolnictwa wyższego skłania się raczej ku modelowi edukacji

\footnotetext{
${ }^{6}$ O podobnych dobrych praktykach współdziałania szkół wyższych, które wykraczają poza standardowe zadania uczelni i przyczyniają się do wyrównania szans studentów z niepełnosprawnością - zob. „Biuletyn Rzecznika Praw Obywatelskich. Zasada równego traktowania - prawo i praktyka" $2015 \mathrm{nr} 16$ Dostępność edukacji akademickiej dla osób z niepetnosprawnościami, s. 50-53.
} 
włączającej (czyli integrującej studentów z niepełnosprawnością z pracą całej grupy podczas wspólnych zajęć), a nie ku modelowi segregacyjnemu? ${ }^{7}$.

Współpraca MSJO UPJPII z BON UPJPII rozpoczęła się od roku akademickiego 2008/2009, tuż po powstaniu Biura. Należy jednak odnotować fakt, że pracownicy Studium już na długo wcześniej prowadzili ze studentami z niepełnosprawnością zajęcia indywidualne bądź grupowe. System ich organizacji - głównie w sferze administracyjnej - był wszakże dalece niedoskonały, mimo iż motywacja ze strony lektorów i osiągane wyniki pod względem poziomu i efektów niewiele odbiegały od zajęć realizowanych standardowo. Jednak świadomość istnienia specjalnych regulacji prawnych i możliwości wpływa na uporządkowanie pracy wykładowców MSJO, działa na ich korzyść i w efekcie - na korzyść samych studentów. Na przykład regulacja dotycząca dostosowania formy egzaminu do konkretnych potrzeb słuchaczy z określoną niepełnosprawnością wyszła naprzeciw oczekiwaniom lektorów oraz niejednokrotnie żywo dyskutowanemu problemowi sposobu egzaminowania i zakresu wymagań końcowych na zajęciach językowych ${ }^{8}$.

Pomoc osób przygotowanych zawodowo do pracy ze studentem z niepełnosprawnością (w przypadku UPJPII - możliwość stałego kontaktu z psychologiem, a zarazem koordynatorem wszystkich działań ze strony BON) stanowi wyjątkowe usprawnienie. Tym bardziej że treść wielu orzeczeń o niepełnosprawności ma zwykle charakter ogólnikowy, pozbawione są one omówienia specyfiki danej dysfunkcji z przełożeniem na konkretne wskazania metodyczne (brak uszczegółowień dotyczących nauczania języków) ${ }^{9}$. Pomoc wspomnianej kompetentnej osoby jest nieoceniona

7 Zob. Dostępność edukacji akademickiej dla osób z niepetnosprawnościami, dz. cyt., s. 5. Szerzej na ten temat: E. Domagała-Zyśk, Idea integracji a potrzeby niestyszacych studentów w zakresie uczenia się języków obcych w szkołach wyższych, w: Student niepełnosprawny. Wybrane konteksty, red. S. Byra, M. Parchomiuk, Lublin 2010, s. 155-165; B. Harań, Kształcenie studentów niepełnosprawnych w zakresie języków obcych, Siedlce 2005.

${ }^{8}$ Zob. B. Harań, Kształcenie studentów niepełnosprawnych w zakresie języków obcych, dz. cyt., s. 48 .

9 Zob. K. Karpińska-Szaj, Rehabilitacyjne aspekty nauczania języków obcych $w$ badaniach i praktyce, w: Indywidualizacja nauczania języków obcych. Badania i praktyka, red. J. Małocha, Kraków 2014, s. 17-18. 
i realizowana na bieżąco w miarę pojawiających się kolejnych wątpliwości, począwszy od problemów czysto lokalowych (brak pomieszczenia przeznaczonego tylko do pracy ze studentami z niepełnosprawnością) po dylematy psychologiczne (np. destrukcyjny wpływ ingerencji rodziców w kwestie samodzielności studenta i jego decyzyjność).

1.4.1. Regulamin korzystania z indywidualnych lektoratów językowych

Ze względu na fakt, że pracownicy MSJO w najszerszym zakresie w skali całej uczelni współpracują z BON, zaś studenci z niepełnosprawnością wykazują żywe zainteresowanie nauką języków, opracowano specjalny regulamin korzystania $\mathrm{z}$ indywidualnych lektoratów na UPJPII, który wszedł w życie 1 października 2012 roku.

Zakłada on, iż z indywidualnych zajęć językowych mogą korzystać osoby mające aktualne orzeczenie o niepełnosprawności (wydane przez ZUS lub Zespół ds. Orzekania o Niepełnosprawności). Studenci realizują owe lektoraty w zamian za konkretne standardowe godziny, które mieliby realizować w grupie (czasami, jednak rzadko, student mógł korzystać z obu form zajęć: grupowych i indywidualnych).

Decyzję o przyznaniu indywidualnego lektoratu podejmuje Pełnomocnik Rektora UPJPII ds. Osób Niepełnosprawnych wraz z kierownikiem MSJO UPJPII. Ten ostatni z kolei niejednokrotnie zasięga opinii osoby, która prowadziła już wcześniej zajęcia z danym studentem i potrafi ocenić jego możliwości percepcyjne. Praktykowane jest także zgłaszanie przez lektora faktu obecności na jego zajęciach grupowych studenta $\mathrm{z}$ niepełnosprawnością, który wyraża wolę indywidualnej pracy, a wcześniej nie był zorientowany w możliwości uzyskania takiego lektoratu (dotyczy to głównie słuchaczy I roku, którzy dopiero zapoznają się $\mathrm{z}$ realiami życia uczelni).

Decyzje o przyznaniu indywidualnego lektoratu podejmowane są w ciągu pierwszego miesiąca każdego roku akademickiego. Choć zdarzają się też sytuacje (średnio 2-3 razy w ciągu roku), kiedy zajęcia takie rozpoczęły się od II semestru. Kilkakrotnie decydowano również o przedłużeniu lektoratu poza wymiar programowy, ale już na zasadzie zajęć z całą grupą (standardowy lektorat lub fakultet językowy) i po uprzedniej zgodzie dziekana danego wydziału i kierunku. 
Warunek konieczny, jaki musi spełnić student, by uzyskać pozwolenie na indywidualny lektorat, to posiadanie takiego rodzaju niepełnosprawności, która w sposób znaczący utrudnia lub uniemożliwia naukę języka obcego na zajęciach grupowych, w tym przede wszystkim:

- ograniczone widzenie lub brak wzroku,

- ograniczony słuch lub głuchota,

- zaburzenia neurologiczne skutkujące problemami z koncentracją uwagi, myśleniem, procesami poznawczymi ${ }^{10}$.

Student, który chce uzyskać zgodę na indywidualny lektorat, składa do BON specjalny wniosek wraz z kopią aktualnego orzeczenia o niepełnosprawności, jeżeli nie została ona złożona już wcześniej ${ }^{11}$. Przyjęcie formy podania i wzajemnej „umowy” pomiędzy studentem a Biurem i tym samym pracownikami MSJO bywa bardzo mobilizujące dla słuchacza. Jak się zaś okazuje, niektórzy studenci takiego właśnie zdyscyplinowania bardzo potrzebują, nawet w wymiarze terapeutycznym.

BON może odmówić studentowi indywidualnego lektoratu, np. z powodu braku funduszy ${ }^{12}$. Chodzi w tym przypadku o dobre, czyli uzasadnione, wykorzystanie dość ograniczonych środków z corocznej dotacji PFRON ${ }^{13}$. Ostatni zapis regulaminowy dotyczy sytuacji pozbawienia

${ }^{10}$ W tym miejscu zarówno BON, jak i MSJO postuluje rozszerzenie zapisu Regulaminu o niepełnosprawności ruchowe, choroby psychiczne oraz całościowe zaburzenia rozwojowe (np. zespół Aspergera).

11 Student zobowiązany jest złożyć wypełniony formularz wniosku o przyznanie indywidualnego lektoratu, w którym znajduje się miejsce na zamieszczenie opinii Pełnomocnika ds. Osób Niepełnosprawnych. Zwykle pojawia się tutaj krótka adnotacja o zgodzie, jeżeli natomiast student nie otrzymałby jej, opinia musi zawierać dłuższe uzasadnienie odmowy.

${ }^{12}$ Do chwili obecnej nie było takich sytuacji na UPJPII, ale teoretycznie taka możliwość odmowy istnieje. Środki - dotacje ze strony Państwowego Funduszu Rehabilitacji Osób Niepełnosprawnych dla studentów z niepełnosprawnością - uczelnia otrzymuje bowiem na podstawie stanu ilościowego studentów z niepełnosprawnością z dnia 30 listopada danego roku. Według relacji pracownika BON są to środki wciąż zbyt szczupłe na zaspokojenie wszystkich potrzeb związanych $\mathrm{z}$ funkcjonowaniem studentów niepełnosprawnych w środowisku akademickim. Zob. Państwowy Fundusz Rehabilitacji Osób Niepetnosprawnych, https://www.pfron.org.pl/pl/pfron/1,PFRON.html (10.11.2016).

${ }^{13} \mathrm{Na}$ ciągły brak odpowiednich warunków technicznych, organizacyjnych, ale również właśnie finansowych zwraca uwagę m.in. prof. Barbara Gąciarz - zob. Wprowadzenie, w: Niepełnosprawni studenci w społeczności akademickiej - źródła sukcesów i porażek wintegracji społecznej i zawodowej, red. B. Gąciarz, Warszawa 2010, s. 26. 
studenta $\mathrm{z}$ niepełnosprawnością prawa do indywidualnych lektoratów i trzeba przyznać, że nie jest to puste i nierealizowane ustalenie. Chodzi o sytuację nieusprawiedliwionego opuszczania zajęć w wymiarze co najmniej 40 proc. w skali semestru oraz wypadki rażącego i niekulturalnego zachowania wobec pracowników MSJO i BON. W dotychczasowej praktyce (biorąc pod uwagę okres ostatnich pięciu lat akademickich, czyli od roku 2011/2012) już kilkakrotnie zrezygnowano z prowadzenia przyznanego lektoratu indywidualnego. Sytuacja dotyczyła studentów, którzy nie korzystali regularnie z zajęć, nie zgłaszali swojej nieobecności na wcześniej ustalonych spotkaniach, nie kontaktowali się z lektorem, notorycznie nie przygotowywali się do zajęć i jak się ostatecznie okazało - niektórzy $\mathrm{z}$ nich byli w stanie odbywać lektorat $\mathrm{z}$ całą grupą ${ }^{14}$.

\subsection{Proces administracyjnego przygotowania ze strony MSJO} do pracy indywidualnej ze studentami z niepełnosprawnością

W październiku każdego roku akademickiego (częściowo również we wrześniu, jeśli lektorat jest kontynuacją) przygotowywana jest obsada pracowników MSJO prowadzących zajęcia indywidualne. Do jej wykonania niezbędne jest posiadanie szeregu informacji odnośnie do beneficjentów systemu: $\mathrm{z}$ jakiego kierunku jest dany student; jakie w związku z tym języki i w jakim wymiarze będzie realizował w trybie indywidualnym; czy sprawa dotyczy tylko języków nowożytnych (jeżeli tak, to jakich), czy również starożytnych (tzn. łaciny i/lub greki).

Przy wyborze osoby lektora do prowadzenia zajęć indywidualnych Kierownictwo MSJO kieruje się zasadą wolnej woli pracownika i zdrowego rozsądku. Lektor musi bowiem mieć czas na dodatkowe obowiązki, również w wymiarze poza właściwymi spotkaniami, kiedy w grę wchodzi przygotowanie zindywidualizowanych materiałów dydaktycznych.

\footnotetext{
${ }^{14}$ Jako studium negatywnego przypadku trzeba przytoczyć skrajną sytuację, kiedy to student $\mathrm{z}$ niepełnosprawnością w sposób świadomy próbował nadużyć możliwości pracy na indywidualnych zajęciach z języka łacińskiego i angielskiego - zgłaszał się na spotkania, chciał przedmiot zaliczać i pisać kolokwia, de facto od kilku miesięcy nie będąc już aktywnym studentem UPJPII.
} 
Kolejna zasada to wyznaczanie osób, które mają już doświadczenie w pracy ze studentem niepełnosprawnym i chętnie się jej podejmują. W każdym semestrze, a w konsekwencji w każdym roku lektoraty indywidualne prowadzi około 50-60 proc. pracowników MSJO (tj. 12-13 osób) ${ }^{15}$. Sekretariat BON przygotowuje dla nich umowy zlecenia, które podpisywane są w większości na początku każdego semestru, a z jego końcem zostają rozliczone. Lektorzy czasami wycofują się z tych zajęć i wówczas studentowi przydzielana jest inna osoba. Powody takich decyzji wynikają z problemów, które zostaną wyszczególnione przy podanej niżej analizie ankiety badawczej.

\section{Zagadnienia dydaktyczno-metodyczne dotyczące pracy indywidualnej ze studentem z niepełnosprawnością - wnioski praktyczne}

\subsection{Indywidualne zajęcia językowe na UPJPII w ujęciu statystycznym}

Prezentacje wniosków praktycznych poprzedzi zbiór zestawień statystycznych dotyczących MSJO, opracowany na podstawie danych przekazanyc przez BON. Na wstępie należy jednak zwrócić uwagę na fakt, że liczbę osób z niepełnosprawnościami uczestniczących w lektoratach podaje się na dany rok akademicki - w tabeli obejmującej okres 5 lat ten sam student może być wykazywany kilkakrotnie w zależności od długości trwania lektoratu (dwa lub trzy lata). W zestawieniach uwzględniono 35 studentów z niepełnosprawnościami, z którymi pracownicy MSJO prowadzili indywidualne zajęcia lektoratowe w okresie od roku akademickiego 2011/2012 do roku 2015/16.

$Z$ analizy tabeli 1 wynika, że najczęściej orzekanymi niepełnosprawnościami występującymi u studentów, z którymi pracownicy MSJO prowadzą zajęcia lektoratowe, są:

\footnotetext{
${ }^{15}$ Często się zdarza, że jeden pracownik prowadzi kilka zajęć indywidualnych w tym samym roku akademickiem, z każdym ze studentów realizując odrębny lektorat.
} 


\begin{tabular}{|c|c|c|c|c|c|c|c|c|c|c|c|c|c|c|}
\hline 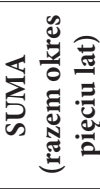 & & ' & 으 & $\exists$ & 字 & $\begin{array}{l}0 \\
\text { n. }\end{array}$ & 6 & 1 & & 1 & $\stackrel{\circ}{\sim}$ & 1 & $\sim$ & H \\
\hline$\stackrel{\circ}{\stackrel{i}{\sim}}$ & $\Xi$ & ' & 1 & $N$ & $N$ & $\sim$ & -1 & 1 & ' & ' & $m$ & ' & - & ' \\
\hline 吕 & - & ' & 1 & -1 & $m$ & $m$ & -1 & ' & ' & ' & $m$ & ' & - & ' \\
\hline$\frac{10}{\mathbb{S}}$ & $\Xi$ & ' & $N$ & -1 & H & 0 & -1 & ' & I & 1 & H & ' & ' & - \\
\hline 공 & - & ' & $\sim$ & - & $H$ & $\wedge$ & -1 & ' & I & 1 & H & ' & I & - \\
\hline 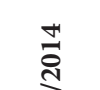 & $\exists$ & ' & $\sim$ & - & $H$ & - & -1 & ' & I & ' & - & ' & ' & I \\
\hline ㄱ. & -1 & ' & $N$ & - & 0 & - & -1 & ' & I & 1 & $\neg$ & ' & ' & 1 \\
\hline$\stackrel{n}{\stackrel{n}{0}}$ & $=$ & ' & 1 & $N$ & in & $m$ & 1 & ' & ' & I & $m$ & ' & ' & I \\
\hline 귱 & 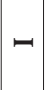 & ' & 1 & $N$ & in & $m$ & 1 & ' & ' & ' & $m$ & ' & ' & ' \\
\hline 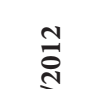 & $\Xi$ & ' & -1 & 1 & $n$ & in & 1 & I & I & 1 & $\sim$ & ' & ' & -1 \\
\hline ন্] & -1 & ' & - & 1 & 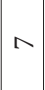 & in & 1 & I & I & 1 & $N$ & 1 & ' & -1 \\
\hline 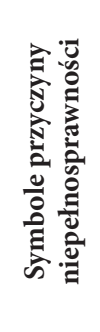 & 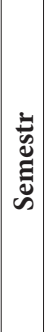 & 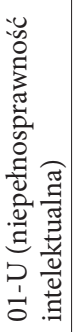 & 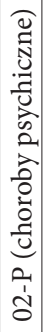 & 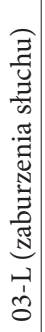 & 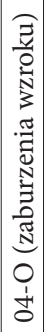 & 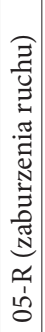 & 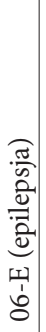 & 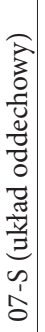 & 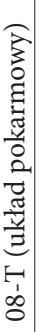 & 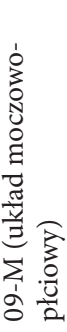 & 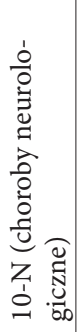 & 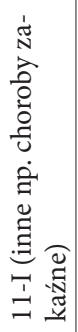 & 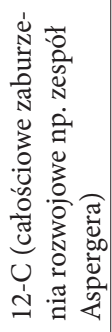 & 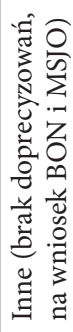 \\
\hline
\end{tabular}


- niepełnosprawność o symbolu: 04-O (choroby narządu wzroku) - 47 studentów,

- niepełnosprawność o symbolu: 05-R (upośledzenie narządu ruchu) - 36 studentów,

- niepełnosprawność o symbolu: 10-N (choroby neurologiczne, np. naczyniopochodny udar mózgu) - 26 studentów ${ }^{16}$.

Tab. 2. Liczba orzekanych niepełnosprawności w odniesieniu do studentów z niepełnosprawnościami korzystających z indywidualnych zajęć językowych, prowadzonych przez pracowników MSJO w poszczególnych latach (w semestrze zimowym i letnim) od roku akademickiego 2011/12 do 2015/16

\begin{tabular}{|c|c|c|}
\hline Rok akademicki & \multicolumn{2}{|c|}{ Liczba orzeczonych niepełnosprawności } \\
\hline Semestr & I & II \\
\hline $2011 / 2012$ & 16 & 16 \\
\hline $2012 / 2013$ & 13 & 13 \\
\hline $2013 / 2014$ & 12 & 10 \\
\hline $2014 / 2015$ & 20 & 19 \\
\hline $2015 / 2016$ & 12 & 11 \\
\hline
\end{tabular}

Tab. 3. Liczba studentów z niepełnosprawnością/niepełnosprawnościami korzystających z indywidualnych zajęć językowych, prowadzonych przez pracowników MSJO w okresie od roku akademickiego 2011/12 do roku 2015/16

\begin{tabular}{|c|c|c|}
\hline Rok akademicki & \multicolumn{2}{|c|}{ Liczba studentów $\mathbf{z}$ niepełnosprawnościami } \\
\hline Semestr & I & II \\
\hline $2011 / 2012$ & 15 & 15 \\
\hline $2012 / 2013$ & 10 & 11 \\
\hline $2013 / 2014$ & 11 & 9 \\
\hline $2014 / 2015$ & 15 & 14 \\
\hline $2015 / 2016$ & 10 & 9 \\
\hline
\end{tabular}

16 Zastosowane w poniższym zestawieniu oznaczenia cyfrowo-literowe, dotyczące określenia rodzaju niepełnosprawności zaczerpnięto z: Rozporządzenie Ministra Gospodarki, Pracy i Polityki Społecznej z dnia 15 lipca 2003 r. w sprawie orzekania o niepełnosprawności i stopniu niepełnosprawności (Dz.U. z 2003 Nr 139, poz. 1328). 
Z zestawienia tabel 2 i 3 wynika jasno, że liczba niepełnosprawności jest większa niż liczba osób z niepełnosprawnościami. Można zatem stwierdzić, iż niektórzy studenci mają orzeczoną więcej niż jedną niepełnosprawność. W tabeli 3 zauważalne są natomiast pewne różnice w liczbie studentów korzystających z indywidualnych zajęć językowych w I i II semestrze danego roku akademickiego. Wynikają one bądź to $\mathrm{z}$ długości trwania lektoratu (np. lektorat jednosemestralny), bądź też z rezygnacji słuchacza $z$ udziału w zajęciach lub wreszcie z jego całkowitej rezygnacji ze studiów.

Tab. 4. Liczba studentów z niepełnosprawnością (niepełnosprawnościami) korzystających z indywidualnych zajęć językowych - podział na poszczególne języki - prowadzonych przez pracowników MSJO w okresie od roku akademickiego 2011/2012 do roku 2015/2016

\begin{tabular}{|l|c|c|c|c|c|c|c|c|c|c|c|c|}
\hline $\begin{array}{c}\text { Rok aka- } \\
\text { demicki }\end{array}$ & \multicolumn{2}{|c|}{$\begin{array}{c}\text { Język } \\
\text { laciński }\end{array}$} & \multicolumn{2}{c|}{$\begin{array}{c}\text { Język } \\
\text { grecki }\end{array}$} & \multicolumn{2}{c|}{$\begin{array}{c}\text { Język } \\
\text { angielski }\end{array}$} & \multicolumn{2}{c|}{$\begin{array}{c}\text { Język } \\
\text { niemiecki }\end{array}$} & \multicolumn{2}{c|}{$\begin{array}{c}\text { Język } \\
\text { włoski }\end{array}$} & \multicolumn{2}{c|}{$\begin{array}{c}\text { Język } \\
\text { rosyjski }\end{array}$} \\
\hline Semestr & I & II & I & II & I & II & I & II & I & II & I & II \\
\hline $2011 / 12$ & 5 & 5 & - & - & 4 & 4 & 2 & 2 & 4 & 4 & 4 & 4 \\
\hline $2012 / 13$ & 4 & 4 & 2 & 2 & 4 & 4 & 2 & 2 & 3 & 3 & 2 & 2 \\
\hline $2013 / 14$ & 2 & 2 & - & - & 7 & 6 & - & - & 4 & 4 & - & - \\
\hline $2014 / 15$ & 3 & 3 & 1 & 1 & 10 & 9 & 1 & 1 & 3 & 3 & - & - \\
\hline $2015 / 16$ & 3 & 3 & - & - & 8 & 6 & - & - & 2 & 3 & - & - \\
\hline SUMA & 17 & 17 & 3 & 3 & 33 & 29 & 5 & 5 & 16 & 17 & 6 & 6 \\
\hline
\end{tabular}

Jak wynika z zaprezentowanej statystyki, największą popularnością wśród języków nowożytnych cieszy się angielski, zaś na drugim miejscu znalazł się język włoski ${ }^{17}$. Duża liczba studentów bierze również udział

17 W związku z popularnością języka angielskiego przy organizacji lektoratów dla studentów niepełnosprawnych z wadami wzroku, słuchu oraz układu ruchu wykorzystywana jest szeroka literatura przedmiotu, m.in.: E. Domagała-Zyśk, Edukacyjne i terapeutyczne wartości lektoratu języka angielskiego dla studentów niesłyszących, w: Przekraczanie barier w wychowaniu osób z uszkodzeniami słuchu, red. K. Krakowiak, A. Dziurda-Multan, Lublin 2006, s. 423-432; E. Domagała-Zyśk, Nauczanie języka angielskiego z uszkodzonym narzqdem stuchu, „Audiofonologia” 13 (2003), s. 127-136; E. Domagała-Zyśk, Specjalne potrzeby edukacyjne niestyszących studentów uczących sięjęzyka angielskiego, w: Procesy poznawcze i język. Klasyczna problematyka - współczesne rozwiązania. Cognition and Language. 
w lektoracie z łaciny, co jednak wynika ze specyfiki uczelni - na niektórych kierunkach (np. teologia, filozofia) jest to przedmiot obowiązkowy.

\subsection{Indywidualne zajęcia językowe na UPJPII oczami lektorów - analiza badania ankietowego}

Opinię lektorów MSJO UPJPII na temat pracy ze studentami z niepełnosprawnością pozwoli przybliżyć analiza przeprowadzonej wśród nich anonimowej ankiety. Badanie to dotyczyło okresu ostatnich pięciu lat akademickich (od 2011/12 do 2015/16), zaś zostało przeprowadzone w lipcu i sierpniu 2016 roku. Grupa respondentów liczyła 12 osób.

Pierwsze pytanie - w formie zamkniętej - dotyczyło rodzaju niepełnosprawności u studenta, z którym dany lektor pracuje. Z otrzymanych odpowiedzi wynika, iż najczęściej w zajęciach uczestniczyli studenci z niepełnosprawnością wzrokową (10 lektorów - 83,3 proc.), zaś na drugim miejscu słuchacze z deficytami ruchowymi (6 lektorów - 50 proc.). Co zresztą koresponduje z przedstawionymi wyżej danymi statystycznymi (por. tab. 1). Część lektorów zaznaczyła również kategorię niepełnosprawności: „Inne” (9 lektorów - 75 proc.) - co wynika z faktu, że czasami prowadzący zajęcia nie wiedzieli dokładnie, z jakim rodzajem niepełnosprawności mają do czynienia (tak dzieje się m.in. w przypadku epilepsji bądź niepełnosprawności o podłożu neurologicznym).

Pytanie drugie (również zamknięte) „W jakich zajęciach uczestniczą/ uczestniczyli Państwa studenci z niepełnosprawnością/niepełnosprawnościami?" wykazało, że ponad połowa studentów z niepełnosprawnością uczestniczy w zajęciach indywidualnych ( 58,3 proc.), a pozostali w zajęciach indywidualnych lub grupowych ( 41,7 proc.).

W mającym formę otwartą pytaniu trzecim: „Proszę wymienić zalety i wady zajęć grupowych i indywidualnych" respondenci więcej uwagi poświęcili zajęciom indywidualnym, ponieważ ta forma przeważa w MSJO.

Classical problems - contemporary solutions, red. K. Ciepiela, Piotrków Trybunalski 2005, s. 159-165; Studenci niewidomi i słabowidzacy - poradnik dla wyższych uczelni. Uczelnia dostępna. Organizacja Systemu Wsparcia. Lektoraty Języków Obcych, red. A. Waszkielewicz, A. Przednowek, Kraków 2007. 
Udzielone odpowiedzi zestawiono poniżej, zachowując ich oryginalną formę.

\begin{tabular}{|c|c|}
\hline \multicolumn{2}{|c|}{ Zajęcia indywidualne } \\
\hline Zalety & Wady \\
\hline $\begin{array}{l}\text { dostosowanie (pod kątem jednej kon- } \\
\text { kretnej osoby i jednej konkretnej nie- } \\
\text { pełnosprawności) narzędzi pracy, ilości } \\
\text { materiału oraz stopnia trudności do indy- } \\
\text { widualnych możliwości studenta } \\
\end{array}$ & brak mobilizacji ze strony grupy \\
\hline lepsze przyswajanie materiału & $\begin{array}{l}\text { brak interakcji między studentami w trak- } \\
\text { cie wykonywania ćwiczeń (grupa często } \\
\text { działa bardziej stymulująco) }\end{array}$ \\
\hline $\begin{array}{l}\text { możliwość dokładnego sprawdzenia } \\
\text { umiejętności i wiedzy }\end{array}$ & $\begin{array}{l}\text { brak możliwości naradzenia się i wymia- } \\
\text { ny myśli z innymi studentami, wspólnego } \\
\text { zastanowienia się nad problemem }\end{array}$ \\
\hline $\begin{array}{l}\text { zwolnienie lub przyśpieszenie tempa pra- } \\
\text { cy w zależności od potrzeb studenta }\end{array}$ & mniejsza dynamika zajęć \\
\hline większy spokój i koncentracja & $\begin{array}{l}\text { brak możliwości porównania swo- } \\
\text { ich umiejętności i postępu w nauczaniu } \\
\text { z osiągnięciami innych studentów }\end{array}$ \\
\hline $\begin{array}{l}\text { możliwość dostosowania intensywności } \\
\text { i czasu zajęć do indywidualnych potrzeb } \\
\text { i możliwości percepcyjnych studenta, zwią- } \\
\text { zanych nie tylko z niepełnosprawnością, } \\
\text { ale też z jego samopoczuciem i ogólnym } \\
\text { nastawieniem w danym dniu (w przypad- } \\
\text { ku choroby psychicznej lub np. epilepsji } \\
\text { ważne jest to, żeby móc w swobodny spo- } \\
\text { sób operować czasem zajęć i ustawiać je } \\
\text { tak, żeby uwzględniać dobry stan psychicz- } \\
\text { ny studenta lub moment po leczeniu ataku } \\
\text { epileptycznego; podobnie przy poważnych } \\
\text { problemach ze wzrokiem) }\end{array}$ & dyskomfort psychiczny studenta \\
\hline komfort w kontakcie z prowadzącym & $\begin{array}{l}\text { niska ocena swoich umiejętności na tle } \\
\text { grupy }\end{array}$ \\
\hline $\begin{array}{l}\text { większe skupienie na osobie studenta, co } \\
\text { umożliwia w dużym stopniu dotarcie do } \\
\text { jego problemów, a dzięki temu ewentual- } \\
\text { ną pomoc, zarówno w płaszczyźnie same- } \\
\text { go nauczania i uczenia się, ale także w sfe- } \\
\text { rze trudności osobistych i życiowych }\end{array}$ & ciągły stres \\
\hline
\end{tabular}




\begin{tabular}{|c|c|}
\hline \multicolumn{2}{|c|}{ Zajęcia indywidualne } \\
\hline Zalety & Wady \\
\hline $\begin{array}{l}\text { szybka reakcja na zadawane pytania i for- } \\
\text { mułowane wątpliwości }\end{array}$ & $\begin{array}{l}\text { brak możliwości pracy grupowej meto- } \\
\text { dą projektów }\end{array}$ \\
\hline $\begin{array}{l}\text { lepsza możliwość sprawdzenia stopnia } \\
\text { zrozumienia omawianego materiału }\end{array}$ & $\begin{array}{l}\text { nieregularność zajęć (odwoływanie ich } \\
\text { czasem w ostatniej chwili) }\end{array}$ \\
\hline $\begin{array}{l}\text { możliwość odrabiana zajęć, które } \\
\text { przepadły }\end{array}$ & $\begin{array}{l}\text { często brak wygodnego miejsca pracy } \\
\text { z tablicą }\end{array}$ \\
\hline \multicolumn{2}{|c|}{ Zajęcia grupowe } \\
\hline Zalety & Wady \\
\hline $\begin{array}{l}\text { większa mobilizacja studenta, np. lepiej } \\
\text { przygotowuje się do kolokwiów }\end{array}$ & $\begin{array}{l}\text { student nie nadąża za grupą, wyłącza się, } \\
\text { zajmuje czymś innym }\end{array}$ \\
\hline $\begin{array}{l}\text { integracja z innymi studentami (wszelkie } \\
\text { walory „uspołecznienia”, możliwość ko- } \\
\text { munikacji językowej z osobami w tym sa- } \\
\text { mym wieku i na podobnym poziomie ję- } \\
\text { zykowym) }\end{array}$ & dyskomfort psychiczny \\
\hline \multirow{3}{*}{$\begin{array}{l}\text { osoba z niepełnosprawnością czuje się } \\
\text { częścią grupy i ma możliwość doświad- } \\
\text { czenia różnych aspektów relacji z innymi } \\
\text { studentami }\end{array}$} & $\begin{array}{l}\text { niska ocena swoich umiejętności na tle } \\
\text { grupy }\end{array}$ \\
\hline & niemożność pracy w tym samym tempie \\
\hline & $\begin{array}{l}\text { nieakceptowanie przez grupę (np. nie- } \\
\text { cierpliwość grupy, gdy trzeba więcej czasu } \\
\text { poświęcić osobie z niepełnosprawnością) }\end{array}$ \\
\hline
\end{tabular}

Kolejne pytanie dotyczyło stosowania konkretnych metod nauczania języków obcych i miało formę otwartą: „Czy stosują/stosowali Państwo specjalne metody nauczania (np. metoda gramatyczno-tłumaczeniowa, audiolingwalna, komunikatywna, Callana itp.) w pracy ze studentami z niepełnosprawnością?". Analizując odpowiedzi, należy rozróżnić nauczanie języków starożytnych i nowożytnych. W pierwszym przypadku bowiem najczęściej stosowaną była metoda gramatyczno-tłumaczeniowa (z dokładną analizą form). Jeżeli zaś chodzi o języki nowożytne, prym wiodły metody audiolingwalna oraz komunikatywna. Zastosowanie danej metody zależy oczywiście od rodzaju niepełnosprawności, np. w przypadku studenta niedowidzącego logiczne jest użycie metody wyjaśnień werbalnych danego zjawiska czy powiększanie rozmiaru czcionki itp.; 
w przypadku natomiast niedosłuchu - ćwiczenia z poprawności czytania (student czasem źle wymawia wyrazy, bo nie umie ich wyartykułować). Kilka osób podkreśliło również, że raczej nie stosują specjalnych metod wobec studentów z niepełnosprawnością.

Pytanie piąte miało również formę otwartą i brzmiało: „Jakie techniki i ćwiczenia stosują/stosowali Państwo w nauczaniu studentów z niepełnosprawnością/ niepełnosprawnościami?". Poniżej przedstawiono uzyskane odpowiedzi:

- dostosowanie standardowych technik i ćwiczeń do możliwości studenta $\mathrm{z}$ niepełnosprawnością,

- $\quad$ praca $\mathrm{z}$ komputerem, $\mathrm{z}$ użyciem specjalnie przygotowanych materiałów (np. powiększonych albo wzbogaconych specjalną grafiką),

- praca na materiałach własnych, dostosowanych do niepełnosprawności studenta, np. dużo ćwiczeń tłumaczeniowych dla osoby niesłyszącej, często mającej problemy z poprawnym formułowaniem pisemnych wypowiedzi (wynika to ze specyfiki języka migowego - braku interpunkcji),

- nagrania poprawnej wymowy,

- uczenie się słownictwa za pomocą fiszek, krzyżówek, kwizów, wykład, wykład z prezentacją multimedialną, ćwiczenia fleksyjne, testy wyboru, testy na rozumienie, skojarzenia,

- ćwiczenia słuchowe z wielokrotnymi powtórzeniami, tłumaczenie wyrazów/zdań,

- ćwiczenia oparte na czytaniu i referowaniu, konwersacje i wyrażanie opinii, niejednokrotnie istniała potrzeba dyktowania wyrazów/zdań,

- dzielenie materiału gramatycznego na mniejsze fragmenty,

- przeprowadzanie odświeżenia tych elementów z zakresu fleksji, które były absolutnie niezbędne do wprowadzenia nowego zagadnienia,

- kopiowanie odmian fleksyjnych/kopiowanie zdań do tłumaczenia, z wprowadzaniem jednego lub dwóch nowych wyrazów,

- upraszczanie do minimum konstrukcji gramatycznych, aby umożliwić pojmowanie zasady ich działania,

- stosowanie mnemotechnik, 
- $\quad$ w przypadku studenta $\mathrm{z}$ chorobą psychiczną (problemy ze skupieniem się) stosowanie metody stałego powtarzania i powrotu do nauczanego materiału,

- w przypadku studenta po porażeniu mózgowym wszystkich kończyn wykonywanie wszystkich notatek osobiście lub na komputerze, aby student mógł je później przejrzeć w domu; zagadnienia gramatyczne przedstawiane były dodatkowo na dużych planszach,

- u osoby z upośledzonym słuchem dialogi musiały być jeszcze dodatkowo przeczytane przez lektora, ponieważ w przypadku puszczania ich z CD student nie słyszał dobrze poszczególnych słów (ze względu na implant), należało mówić głośno i wyraźnie, patrząc wprost na studenta, aby mógł posiłkować się odczytywaniem $\mathrm{z}$ ruchu warg,

- student niewidomy nagrywał zajęcia, w jego przypadku wszystkie ćwiczenia musiały być opisywane głosem (np. ilustracje, scenki itp.), z niektórych trzeba było zrezygnować,

- specjalne rozwiązania techniczne, np. powiększony tekst, lupa, autolektor.

Z kolei otwarte pytanie szóste dotyczyło kwestii dostosowania sposobu oceniania do konkretnej niepełnosprawności: „Czy dostosowują/ dostosowywali Państwo sposób oceniania, uwzględniając rodzaj niepełnosprawności danego studenta (jeżeli tak - proszę podać, w jaki sposób)?”. W uzyskanych odpowiedziach na podkreślenie zasługuje fakt, że zasady oceniania wszystkich studentów są takie same, różnią się jedynie sposoby i formy zdobywania zaliczeń. Respondenci podali tu kilka przykładów:

- wydłużony czas na wypowiedź pisemną lub ustną,

- inna forma wykonania zadania (np. ustna zamiast pisemnej i vice versa),

- mniejsze wymogi poprawności stylistycznej w przypadku studenta $\mathrm{z}$ niedosłuchem,

- towarzyszenie na egzaminie końcowym z języka starożytnego asystenta studenta $\mathrm{z}$ niepełnosprawnością ruchową, który sprawdzał w słowniku formy podstawowe,

- dzielenie materiału na mniejsze jednostki, 
- zapisywanie odpowiedzi w przypadku studenta z porażeniem mózgowym,

- zadanie studentowi niewidomemu zamiast analizy obrazka opisania na podstawie sekwencji muzycznej tego, co widzi oczyma duszy.

W kolejnym punkcie ankiety skupiono się na problemach, jakie najczęściej występują w pracy ze studentami z niepełnosprawnością. Uzyskane odpowiedzi, zapisane poniżej w ich oryginalnym brzmieniu, można podzielić na kilka grup:

I. Problemy techniczne:

- brak internetu,

- problemy z komputerem (awarie lub zbyt wolno działający sprzęt niezbędny do pracy np. ze studentem niewidomym),

- kłopot z salą (np. osoby mające problemy ze słuchem źle pracują w większych pomieszczeniach, odbijających dźwięki).

II. Indywidualne problemy związane z konkretną niepełnosprawnością:

1. problemy z koncentracją i pamięcią,

2. konieczność wielokrotnego powtarzania tych samych zagadnień,

3. obniżona zdolność zapamiętywania, ogólnie trudności w uczeniu się języków,

4. problemy emocjonalne i psychiczne studenta, które mają wpływ na proces uczenia się studenta i przyswajania wiedzy,

5. częste choroby lub nagłe niedyspozycje,

6. izolowanie przez grupę studentów z zespołem Aspergera, odbieranie ich jako skupiających ciągle na sobie zainteresowanie prowadzącego lub niegrzecznych (nagłe wybuchy złości),

7. osoby z zaburzeniami psychicznymi miały problem $\mathrm{z}$ trafieniem na odpowiedni dzień i godzinę zajęć (myliły np. wtorek z czwartkiem),

8. atak epilepsji na zajęciach grupowych wywoływał niepokój u pozostałych studentów.

III. Problemy merytoryczno-metodyczne:

1. brak przygotowania do pracy np. ze studentem niewidomym,

2. niewywiązywanie się studenta $\mathrm{z}$ terminów kolokwiów (np. ciągłe przekładanie terminu pisania testu), 
3. brak odpowiedniego przygotowania studenta do zajęć,

4. brak możliwości ustalenia ścisłych ram czasowych pracy,

5. odwoływanie zajęć,

6. zatrzymanie uwagi studenta na całych zajęciach,

7. wątpliwości co do wysokości stawianych wymagań i sposobu ich egzekwowania.

Pytanie ósme miało formę otwartą i brzmiało: „Jak Państwo argumentują problemy i ewentualnie niepowodzenia, które pojawiały się w pracy ze studentem $\mathrm{z}$ niepełnosprawnością (niepełnosprawnościami)?”. Jedną z najczęściej padających odpowiedzi był brak profesjonalnej wiedzy co do tego, jak należy pracować $\mathrm{z}$ danym studentem, a skutkiem tego - opieranie się na intuicji, dotychczasowym doświadczeniu i dochodzenie do właściwych efektów metodą prób i błędów. Respondenci wymieniali również problemy wynikające z ograniczeń, jakie niesie ze sobą niepełnosprawność. Na przykład student z epilepsją może mieć bardzo ograniczoną zdolność koncentracji z powodu zażywanych leków lub zmęczenia po przebytym ataku. Czasami dochodzą do tego również deficyty natury intelektualnej, powodujące trudności w opanowaniu nowego materiału oraz brak systematyczności w nauce. Zdaniem ankietowanych źródłem problemów może być też nastawienie studenta, który traktuje zajęcia jako kolejny przedmiot do zaliczenia. Nie mniej utrudniali pracę słuchacze nieodpowiedzialni, którzy nie przychodzili na ustalone zajęcia indywidualne i nie usprawiedliwiali swojej absencji lub odwoływali spotkania kwadrans po ich teoretycznym rozpoczęciu. Bazując na udzielonych odpowiedziach, można więc wyciągnąć wniosek, iż problemy studentów niepełnosprawnych tylko w części odbiegają od kłopotów osób bez orzeczenia. Zaś niejednokrotnie rozmowa motywująca lub polecenie odpowiednich serwisów, programów czy podręczników wystarczyły, aby student poczuł się pewniej.

Właśnie kwestii motywowania do pracy dotyczyło pytanie dziewiąte o brzmieniu: „W jaki sposób wspierają i motywują/wspierali i motywowali Państwo studentów z niepełnosprawnością/niepełnosprawnościami?". Korzystając z otwartej formy pytania, wielu ankietowanych podkreśliło, że większość studentów jest silnie zmotywowana do nauki języków. Ponadto prowadzący wymienili następujące stosowane sposoby motywacji (zapis w wersji oryginalnej): 
- dostosowanie metod do potrzeb i oczekiwań studentów, pochwały, wchodzenie na ambicję, interesowanie się osobą ucznia w kontekście przydatności znajomości języka w przyszłości, dodatkowe materiały na prośbę studenta,

- w razie trudności łatwiejsze przykłady, ćwiczenia; wydłużanie czasu pracy; materiały do domu do spokojnego przejrzenia,

- pokazywanie przydatności języka przy czytaniu tekstów oryginalnych, przy szukaniu pracy np. w archiwach, przy uczeniu się kolejnych języków, wskazywanie obecności nauczanego języka w języku polskim, co wiąże się z właściwym rozumieniem pojęć i poprawnym ich używaniem, ukazywanie możliwości rozumienia określonych kodów kulturowych,

- zachęcanie do ćwiczenia pamięci, chwalenie nawet bardzo małych sukcesów podczas zajęć,

- „dowartościowywanie”, czyli podkreślanie mocnych stron studenta przy nauce języka,

- student z chorobą psychiczną wymagał czasami zdecydowanej reakcji, „potrząśnięcia”, przymuszenia do pracy, zmobilizowania, a nawet „przestraszenia” konsekwencją braku zaliczenia czy możliwości zdania egzaminu,

- chwalenie postępów, motywowanie do wysiłku, omawianie progresu, zauważanie mocnych stron,

- odsłuchiwanie wiadomości w oryginale i zrozumienie tych tekstów.

Pytanie dziesiąte - o strukturze zamkniętej - służyło ocenie skuteczności nauczania języków obcych. Połowa ankietowanych określiła ją jako „wystarczającą”, a ponad 33 proc. jako „dobrą”. Interesująca natomiast jest równowaga na poziomie 8,3 proc., jaka ustaliła się między skutecznością „bardzo dobrą” a „znikomą”.

Kolejne pytanie pozwoliło na zbadanie nastawienia studentów z niepełnosprawnością do nauki języków obcych z punktu widzenia lektorów. W tym celu respondenci posiłkowali się pięciostopniową skalą, w której „1” oznaczało postawę „całkowicie negatywną", zaś „5” - „bardzo pozytywną". Nastawienie odpowiadające ocenom „1” i „2” nie zostało wskazane przez żadnego $\mathrm{z}$ ankietowanych. Natomiast postawa na poziomie 
średnim pojawiła się u 2 (17 proc.) respondentów, nastawienie „dobre” u 33 proc., zaś „bardzo dobre” aż u połowy ankietowanych.

Pytanie dwunaste dotyczyło tylko lektorów pracujących z osobami z niepełnosprawnością na zajęciach grupowych i oceny ich interakcji z kolegami: „Jak kształtują się relacje między studentami z niepełnosprawnością/niepełnosprawnościami a pozostałą częścią grupy na zajęciach językowych?". W udzielonych odpowiedziach przeważały opinie o dobrej kooperacji. W opinii lektorów grupa często służy wsparciem, wykazuje się tolerancją i chęciom udzielania pomocy. Czasami jednak studenci bez niepełnosprawności wykazują brak zrozumienia, zdystansowanie, niechęć, agresję i zniecierpliwienie, a czasami - obojętność. Jeden z respondentów zauważył na początku semestru dosyć dużą rezerwę i zniecierpliwienie grupy w stosunku do studenta z zespołem Aspergera. Dopiero po zorganizowaniu spotkania, na którym wyjaśniono specyfikę tegoż schorzenia, relacje zdecydowanie się polepszyły i zaobserwowano dużą chęć współpracy ze strony grupy.

Ostatnie pytanie dawało respondentom możliwość swobodnej wypowiedzi na temat pozytywnych lub negatywnych doświadczeń, jakie zdobyli w pracy ze studentem z niepełnosprawnością. Poniżej zacytowano opinie in plus:

- pozytywne i rozwijające doświadczenie - kontakt z drugim człowiekiem,

- studenci ci są z reguły silnie zmotywowani i pracowici, ich zaangażowanie i determinacja często są silnym „mobilizatorem” dla prowadzącego zajęcia. Stanowi też nieoceniony zasób wiedzy na temat innego sposobu funkcjonowania, uczenia się i odbioru rzeczywistości,

- praca twórcza, przynosząca efekty. Niektóre pomysły, które pojawiają się w trakcie, można wykorzystać w pracy z innymi studentami,

- od studenta niewidomego dowiedziałam się, że nie lubi śniegu, bo traci orientację, i że uwielbia chodzić na mecze, żeby je „słyszeć”,

- dzięki zajęciom indywidualnym mam większą możliwość poznania studenta i nawiązania $\mathrm{z}$ nim głębszego kontaktu, na co brakuje często czasu w zajęciach grupowych, 
- jest to praca bardzo wymagająca, zajmująca dużo czasu, jeżeli jednak student wraz z nauczycielem wykorzysta ten czas i współpracują razem, to efekt końcowy (konwersacja w danym języku obcym na koniec lektoratu) jest najlepszą nagrodą dla obydwu stron. Natomiast wśród opinii negatywnych pojawiły się następujące:

- wykorzystywanie niepełnosprawności np. do usprawiedliwiania ciągłego braku przygotowania,

- bardzo ciężka praca, wymagająca sporej ilości czasu na przygotowania. Męcząca - także psychicznie. Trudno prowadzić zajęcia 90 minut.

\section{Podsumowanie}

Przytoczone powyżej wyniki badań ankietowych pozwalają spojrzeć na pracę ze studentami z niepełnosprawnością z kilku perspektyw. Z jednej strony bowiem z odpowiedzi respondentów wyraźnie wynika, iż praca ta wymaga od nich wielogodzinnego przygotowania i zaangażowania (również emocjonalnego). Z drugiej jednak strony lektorzy deklarują, że poziom osiągniętej satysfakcji zawodowej i zadowolenia $\mathrm{z}$ wyników podjętego wysiłku rekompensuje wszelkie trudności.

Przy ocenie zalet i wad pracy indywidualnej wyraźnie podkreślono pozytywną opinię na temat tej formy działania edukacyjnego, zaś przy opisie pracy grupowej wskazano wiążące się z nią trudności (np. niejednokrotnie pojawiające się zniecierpliwienie ze strony grupy, gdy osoba prowadząca zajęcia musi więcej czasu poświęcić studentowi z niepełnosprawnością). Z kolei o oryginalności ujęcia analizowanego tematu świadczy uwzględnienie w ankiecie obserwacji i uwag lektorów języków starożytnych, w sytuacji gdy badania nad zagadnieniem pracy ze studentem z niepełnosprawnością ograniczają się zwykle do nauczania języków nowożytnych.

Analiza wyników przeprowadzonej ankiety - stwarzająca sposobność do wymiany doświadczeń z zakresu stosowanych metod, technik, narzędzi i ćwiczeń - jest doskonałym źródłem wiedzy dla dydaktyków. A jednocześnie stanowi nieocenioną pomoc dla pracowników Biura 
Osób Niepełnosprawnych i kierownictwa Międzywydziałowego Studium Języków Obcych UPJPII, jako źródło informacji pozwalających na sprawniejszą organizację pracy od strony logistyczno-administracyjnej.

$\mathrm{W}$ ramach podsumowania warto przytoczyć jedną $\mathrm{z}$ wypowiedzi, która pojawiła się w omawianej ankiecie, a która oddaje blaski i cienie oraz specyfikę prowadzenia zajęć językowych ze studentem z niepełnosprawnością:

To jest taki typ pracy, który jest czasami wyzwaniem. Wymaga cierpliwości i skrupulatności (ciągła analiza możliwości percepcyjnych studenta uwarunkowanych zmieniającym się stanem zdrowia) i szybkiego reagowania na bieżąco. Z drugiej strony to praca, która (choć wspomagana konkretnymi środkami i narzędziami) wymaga sporego „wczucia się" w drugiego człowieka, czyli umiejętności interpersonalnych. Mnie przynosi ogromną satysfakcję i oprócz podstawowego zadowolenia, że studentowi udało się pokonać własną słabość, ciągle utwierdza mnie w przekonaniu, że jest to zwykła praca, nic nadzwyczajnego, jak praca z każdym innym studentem. Nie odbieram tej pracy jako specjalnego posłannictwa, to są zwykłe, choć czasami niezwykłe zajęcia.

\section{Bibliografia i netografia}

Domagała-Zyśk E., Edukacyjne i terapeutyczne wartości lektoratu języka angielskiego dla studentów niestyszących, w: Przekraczanie barier w wychowaniu osób z uszkodzeniami słuchu, red. K. Krakowiak, A. Dziurda-Multan, Lublin 2006, s. 423-432.

Domagała-Zyśk E., Idea integracji a potrzeby niestyszących studentów wakresie uczenia się języków obcych w szkołach wyższych, w: Student niepelnosprawny. Wybrane konteksty, red. S. Byra, M. Parchomiuk, Lublin 2010, s. 155-165.

Domagała-Zyśk E., Nauczanie języka angielskiego z uszkodzonym narządem stuchu, „Audiofonologia” 13 (2003), s. 127-136.

Domagała-Zyśk E., Specjalne potrzeby edukacyjne niestyszacych studentów uczacych sie języka angielskiego, w: Procesy poznawcze i język. Klasyczna problematyka - wspótczesne rozwiązania. Cognition and Language. Classical problems contemporary solutions, ed. K. Ciepiela, Piotrków Trybunalski 2005, s. 159-165. 
„Biuletyn Rzecznika Praw Obywatelskich. Zasada równego traktowania - prawo i praktyka” 2015 nr 16 Dostępność edukacji akademickiej dla osób z niepełno sprawnościami.

Harań B., Kształcenie studentów niepełnosprawnych w zakresie języków obcych, Siedlce 2005.

Jedyne w swoim rodzaju Porozumienie międzyuczelniane, http://www.up.krakow.pl/bon/wspolpraca.html (13.11.2016).

Karpińska-Szaj K., Rehabilitacyjne aspekty nauczania języków obcych w badaniach i praktyce, w: Indywidualizacja nauczania języków obcych. Badania i praktyka, red. J. Małocha, Kraków 2014, s. 8-21.

Konwencja ONZ o prawach osób niepełnosprawnych z dnia 13 grudnia 2006 r., https://www.rpo.gov.pl/pl/konwencja-o-prawach-osob-niepelnosprawnych (13.11.2016).

Niepełnosprawni studenci w społeczności akademickiej - źródła sukcesów i porażek w integracji społecznej i zawodowej, red. B. Gąciarz, Warszawa 2010.

Państwowy Fundusz Rehabilitacji Osób Niepełnosprawnych, https://www.pfron. org.pl/pl/pfron/1,PFRON.html (10.11.2016).

Studenci niewidomi i słabowidzący - poradnik dla wyższych uczelni. Uczelnia dostępna. Organizacja Systemu Wsparcia. Lektoraty Języków Obcych, red. A. Waszkielewicz, A. Przednowek, Kraków 2007.

Ustawa z dnia 27 lipca 2005 r. Prawo o szkolnictwie wyższym (Dz. U. z 2012, poz. 572).

Regulaminu studiów pierwszego stopnia, drugiego stopnia oraz jednolitych studiów magisterskich, http://www.upjp2.edu.pl/sites/default/files/Regulamin (12.11.2016).

Rozporządzenie Ministra Nauki i Szkolnictwa Wyższego z dnia 25 września 2014 r. w sprawie warunków, jakim muszą odpowiadać postanowienia regulaminu studiów w uczelniach (Dz. U. z 2014, poz. 1302).

Rozporządzenie Ministra Gospodarki, Pracy i Polityki Społecznej z dnia 15 lipca 2003 r. w sprawie orzekania o niepełnosprawności i stopniu niepełnosprawności (Dz. U. z 2003 Nr 139, poz.1328). 


\section{Abstract}

On the one hand this article aims at presenting the work activities of the Interfaculty Department of Foreign Languages in association with the Disability Support Service at our university and the legal regulations (both internal and external) that relate to this issue. Therefore, we will describe the procedures applied at the beginning of each academic year when choosing specific one-toone (teacher-student) groups. We will also present the factors taken into account in the organisation of teaching of disabled students.

On the other hand the article presents methodological challenges which arise in the course of working with a disabled student. Our observations and conclusions related to the process of teaching ancient and modern languages are based on the long teaching experience of our language instructors. We have analysed data for five consecutive academic years (starting from academic year 2011-2012 to 2015/2016). The analysis is based on the responses to a questionnaire, given by the teachers of the Interfaculty Department of Foreign Languages at the end of the academic year 2015-2016.

We would like to give our thanks to all language instructors who answered the questionnaire for their pertinent, credible and insightful comments relating to their work with disabled students.

Słowa kluczowe: biuro ds. osób niepełnosprawnych, nauczanie języków obcych w przypadku studentów z niepełnosprawnościami, metodologia nauczania

Keywords: the disability support service, teaching foreign languages to students with disabilities, the teaching methodology 


\section{Aneks}

Ankieta dotycząca nauczania języków obcych studentów z niepełnosprawnością. Dotyczy pracy ze studentem/studentami z niepełnosprawnością/niepełnosprawnościami na przestrzeni ostatnich pięciu lat akademickich (od 2011/12 do 2015/16).

1. Jaki rodzaj niepełnosprawności mają/mali Państwa studenci (można wybrać więcej niż jedną odpowiedź)?

02-P (choroby psychiczne np. zaburzenia nastroju, stany lekowe, zespół otępienia...)

$\square$ 03-L (słuch, zaburzenia głosu, mowy...)

$\square$ 04-O (wzrok)

$\square$ 05-R (ruch)

$\square$ 06-E (epilepsja)

$\square$ 05-R (ruch)

$\square \quad 10-\mathrm{N}$ (neurolog, np. choroby rdzenia kręgowego i inne)

$\square$ 12-C (całościowe zaburzenia rozwojowe np. zespół Aspergera)

$\square$ Inne

2. W jakich zajęciach uczestniczą/uczestniczyli Państwa studenci $\mathrm{z}$ niepełnosprawnością/niepełno sprawnościami?

$\square$ zajęcia indywidualne

$\square$ zajęcia grupowe

$\square$ zajęcia indywidualne lub grupowe

3. Proszę wymienić zalety i wady powyższych form zajęć (grupowych bądź indywidualnych)?

4. Czy stosują/stosowali Państwo specjalne metody nauczania (np. metoda gramatyczno-tłumaczeniowa, audiolingwalna, komunikatywna, Callana itp.) w pracy ze studentami z niepełnosprawnością?

5. Jakie techniki i ćwiczenia stosują/stosowali Państwo w nauczaniu studentów z niepełnosprawnością/niepełnosprawnościami?

6. Czy dostosowują/dostosowywali Państwo sposób oceniania, uwzględniając rodzaj niepełnosprawności danego studenta (jeżeli tak proszę podać, w jaki sposób)? 
7. Jakie problemy występują/występowały najczęściej w Państwa pracy ze studentami z niepełnosprawnością/niepełnosprawnościami?

8. Jak Państwo argumentują problemy, ewentualnie niepowodzenia, które pojawiały się w pracy ze studentem z niepełnosprawnością/niepełnosprawnościami?

9. W jaki sposób wspierają i motywują/wspierali i motywowali Państwo studentów z niepełnosprawnością/niepełnosprawnościami?

10. Jak oceniają Państwo skuteczność nauczania języków obcych studentów z niepełnosprawnością/niepełnosprawnościami?

brak skuteczności nauczania

$\square$ znikoma (bardzo mała) skuteczność nauczania

$\square$ częściowa (wystarczająca) skuteczność nauczania

$\square$ dobra skuteczność nauczania

bardzo dobra skuteczność nauczania

11. Jak Państwo oceniają nastawienie studentów z niepełnosprawnością/niepełnosprawnościami do uczenia się języków obcych (1 - całkowicie negatywnie, 5 - bardzo pozytywnie)?

\begin{tabular}{|l|l|l|l|l|}
\hline 1 & 2 & 3 & 4 & 5 \\
\hline & & & & \\
\hline
\end{tabular}

12. Jak kształtują się relacje między studentami z niepełnosprawnością/niepełnosprawnościami a pozostałą częścią grupy na zajęciach językowych (dotyczy pracowników mających osoby z niepełnosprawnością/niepełnosprawnościami na zajęciach grupowych)?

13. Jak oceniają Państwo swoje doświadczenia w pracy ze studentem z niepełnosprawnością/niepełnosprawnościami (doświadczenia pozytywne lub negatywne)? 